\title{
PROSPEK PENGEMBANGAN USAHA PENGOLAHAN PEMPEK PALEMBANG
}

\author{
Theresia Dwi Suryaningrum dan ljah Muljanah*)
}

\begin{abstract}
ABSTRAK
Pempek merupakan makanan khas Palembang yang sudah dikenal luas secara nasional sebagai makanan yang gurih dan bergizi. Pempek pertama kali dibuat dengan menggunakan ikan belida (Notopterus $s p$ ) atau ikan gabus (Ophiocephalus $s p$ ), yaitu ikan asli sungai Musi yang mempunyai daging putih dan rasa gurih yang khas. Namun karena sumberdaya kedua jenis ikan tersebut semakin langka, sekarang pempek dibuat dari ikan sungai maupun ikan laut. Di pasaran ada 2 jenis pempek yaitu pempek basah dan pempek kering. Pada prinsipnya pengolahan pempek terdiri atas pembersihan dan pemfiletan ikan, pelumatan daging, pengadukan adonan, pencetakan dan pemasakan, sedangkan untuk pempek kering diperlukan satu tahap lagi yaitu pengeringan dengan menggunakan alat pengering mekanik. Alat pengering mekanik pempek yang dirancang oleh Balai Besar Riset Pengolahan Produk dan Bioteknologi Kelautan dan Perikanan Jakarta berupa kabinet yang dilengkapi dengan rak dan sumber panas berasal dari gas elpiji. Kelemahan dari pempek kering adalah perlu direhidrasi (direndam dalam air) dan direbus kembali sebelum disajikan. Usaha pengolahan pempek cukup prospektif, pangsa pasarnya cukup luas karena digemari oleh sebagian besar masyarakat, teknologi pengolahannya sederhana, bahan bakunya mudah diperoleh serta keuntungan yang diperoleh cukup menjanjikan. Oleh karena itu pengembangan usaha pengolahan pempek Palembang merupakan alternatif sebagai mata pencaharian dalam krisis ekonomi global saat ini.
\end{abstract}

\section{ABSTRACT: Prospect and development of processing business of pempek Palembang. By: Theresia Dwi Suryaningrum and ljah Muljanah}

Pempek is a traditional food from Palembang that is also widely known nationally as a delicious and nutritious meal. Pempek was originally made by using Notopterus sp. and Ophiocephalus sp., both of them are native species of Musi River, containing a white meat and a distinctive taste. However, due to the limited availability of both species, pempek nowadays are made of fresh water and marine fishes. In the market, there are two kinds of pempek, wet pempek and dry pempek. In principle, the processing of pempek consisting of cleaning and filleting process of raw fishes, grinding, stirring, pressing and cooking. There is one additional step in the processing of dry pempek, that is drying process by using a mechanical dryer. This device is successfully engineered by the Research Center of Marine and Fisheries Product Processing and Biotechnology in a form of a cabinet, equipped with rack and a heat source from LPG. The weaknesses of dry pempek are the requirement of re-hydration and re-heat prior to serve. The processing business of pempek is very prospective, with a wide marketing target, a simple processing technology, abundant availability of raw material, and a promising profit. Thus the development of processing business of pempek Palembang nowadays is an alternative to answer the economic problem due to the recent global crisis.

\section{KEYWORDS: $\quad$ pempek, dryer, business analysis}

\section{PENDAHULUAN}

Pempek merupakan makanan khas Palembang yang dibuat dari campuran daging lumat ikan, tepung tapioka, air dan garam. Pempek dijual dalam berbagai bentuk seperti pempek lenjeran yang berbentuk bulat panjang (panjang $15 \mathrm{~cm}$ dan diameter $4 \mathrm{~cm}$ ) pempek kapal selam yang diisi dengan telur, pempek adaan yang diberi bumbu bawang putih berbentuk bulat, pempek keriting seperti mi dan lain-lain (Anon, 2006). Nama pempek berasal dari kosa kata "apek" yaitu sebutan untuk lelaki tua keturunan Cina yang pertama kali membuat dan menjajakan makanan tradisional tersebut secara keliling. Oleh karena penjualnya dipanggil dengan pek...apek, maka makanan olahan tersebut akhirnya dikenal sebagai pempek atau mpekmpek. Pempek ini biasanya dimakan dengan cuko atau saus asam manis dan pedas sehingga rasanya enak dan menyegarkan. Pada mulanya ikan yang digunakan dalam pembuatan pempek ini adalah ikan belida (Notopterus sp.) atau ikan gabus (Ophiocephalus sp.). Ke dua jenis ikan tersebut

*) Peneliti pada Balai Besar Riset Pengolahan Produk dan Bioteknologi Kelautan dan Perikanan 
merupakan ikan perairan umum yang hidup di sungai Musi atau rawa-rawa di Sumatera Selatan yang pada saat itu sumberdayanya sangat melimpah. Namun karena sumberdaya kedua jenis ikan tersebut semakin langka maka saat ini pempek dibuat dengan menggunakan ikan sungai lainnya misalnya ikan toman (Ophiocephalus melanosoma) dan kutuk/putak (Ophicephalus striatus), sejenis ikan gabus. Jenisjenis ikan laut juga dapat dipakai sebagai bahan pempek seperti tenggiri (Scoberomorus sp.), ikan kakap merah (Lutjanus sanguineus), parang-parang (Chirocentrus sp.) dan ikan sebelah (Pseudorhombus sp.) (Anon, 2008). Pengolahan pempek selain merupakan diversifikasi pengolahan ikan, juga memberikan nilai tambah menjadi produk siap saji serta dapat meningkatkan peluang usaha. Di Palembang kini terdapat ratusan industri rumah tangga yang mengolah pempek, sehingga industri tersebut dapat menggerakkan ekonomi dan menjadi sumber pendapatan bagi masyarakat setempat. Pangsa pasar pempek cukup cerah, terutama sebagai oleh-oleh khas Palembang, apalagi bila bulan puasa atau menjelang lebaran. Menurut keterangan petugas bandara, pada saat menjelang dan sesudah lebaran, pempek yang dibawa sebagai oleh-oleh sehari bisa 5 ton (Wawancara Pribadi, 2008). Melihat kenyataan ini pempek cukup diminati, sehingga industri pempek dapat dikembangkan di luar kota Palembang.

Pempek merupakan produk yang bersifat basah sehingga daya awet dan distribusinya sangat terbatas, yaitu hanya tahan sekitar 3 hari pada suhu kamar dan untuk pemasaran keluar daerah biasanya penjual melumurinya dengan tepung tapioka. Penyimpanan lebih dari 3 hari akan menyebabkan terbentuknya lendir pada permukaan produk serta menimbulkan citarasa yang tidak enak. Salah satu usaha untuk meningkatkan daya awet dan memperluas distribusi atau pemasarannya, yaitu dengan mengurangi kadar air dan mengolahnya menjadi bentuk kering. Sampai saat ini pempek kering yang sudah ada di pasaran adalah bentuk mie kering. Kendala yang dihadapi dalam proses pengeringan pempek adalah diperlukan waktu pengeringan yang lama, apalagi pada musim hujan. Bila matahari cukup terik, pengeringan dengan sinar matahari diperlukan waktu 2-3 hari, sedangkan bila cuaca mendung pengeringannya bisa sampai 1 minggu. Selama pengeringan tersebut, tidak tertutup kemungkinan produk terkontaminasi dengan bakteri dan jamur, sehingga seringkali menimbulkan kerugian bagi pengolah. Balai Besar Riset Pengolahan Produk dan Bioteknologi telah merancang alat pengering pempek kering berbentuk kabinet/lemari. Di dalam lemari dilengkapi dengan rak penjemuran yang diatur secara bersusun. Sumber panas berasal dari gas elpiji yang disalurkan melalui pipa yang diberi lubang dengan ukuran mata bor yang paling kecil. Dengan pemanasan tersebut pempek dapat dikeringkan dengan kadar air kurang dari 10\%, sehingga pempek dapat tahan disimpan pada suhu kamar lebih dari 6 bulan.

\section{TEKNOLOGI PENGOLAHAN PEMPEK}

\section{Pengolahan Pempek Basah}

\section{a. Penyiapan bahan baku dan pelumatan daging}

Bahan yang digunakan dalam pengolahan pempek adalah ikan, tepung tapioka, air es, garam dan monosodium glutamat (MSG). Pada prinsipnya pengolahan pempek terdiri atas pembersihan dan pemfiletan ikan, pelumatan daging, pengadukan adonan, pencetakan dan pemanasan, sedangkan untuk pempek kering diperlukan satu tahap lagi yaitu pengeringan dengan menggunakan alat pengering mekanik. Ikan yang digunakan adalah ikan yang berdaging putih dan mempunyai flavour yang kuat. Ikan yang berdaging putih mempunyai kemampuan pembentukan gel yang kuat yang akan berpengaruh terhadap tekstur yang dihasilkan (Tanaka, 2008). Kesegaran ikan menjadi kunci untuk memperoleh citarasa dan tekstur yang baik. Penggunaan ikan sungai akan menghasilkan pempek yang lebih baik dibandingkan dengan ikan laut. Hal ini karena ikan sungai seperti ikan belida, gabus, toman dan lainlain masih hidup sebelum diolah, sehingga flavour dan citarasa belum berubah serta kemampuan pembentukan gel ikan masih sangat tinggi (Gopakumar, 1997). Ikan yang akan diolah menjadi pempek dipotong kepala dan dihilangkan isi perutnya, kemudian difilet, dan diambil dagingnya. Daging filet kemudian dicuci degan menggunakan air es untuk menghilangkan darah serta kotoran lainnya. Daging ikan kemudian dilumatkan dengan menggunakan mesin pelumat daging (mincer). Dalam penyiapan bahan baku yang perlu diperhatikan adalah selama proses penanganan ikan harus dalam kondisi dingin, dengan menambahkan hancuran es.

\section{b. Proses pengadukan}

Daging lumat ikan yang diperoleh kemudian diaduk dengan tangan atau mesin pengaduk dan dicampur dengan air es dengan perbandingan 1:1 dan garam $1,5 \%$. Pengadukan dapat dilakukan dengan tangan atau mesin pengaduk sampai terbentuk adonan yang elastis atau kalis. Pengadukan menyebabkan protein miofibril pecah dan terlarut secara homogen dalam pasta ikan (Niwa, 1985). Miofibril protein memegang peranan penting dalam pembentukan gel terutama dari 
aktomiosin (Suzuki, 1981). Penambahan garam selama pengadukan akan menyebabkan protein miofibril yang larut garam akan keluar dari daging ikan dalam bentuk "sol" yang menyebabkan adonan menjadi lengket dan membentuk tekstur yang elastis (Okada, 1985). Menurut Niwa (1985), tekstur yang lengket tersebut disebabkan adanya ion sodium dan klorida pada garam membentuk ikatan dengan asam dan basa dengan molekul $\mathrm{COO}^{-}$dan $\mathrm{NH}^{+}$dari protein. Menurut Lee (1997) fungsi garam dalam pembuatan adonan selain memberikan rasa asin juga menambah flavour ikan pada pempek. Jumlah garam yang digunakan untuk pembuatan pempek berkisar antara 1,5-3\% dari bobot ikan yang digunakan.

Air es yang digunakan dalam pembuatan pempek dimaksudkan untuk mempertahankan suhu selama pengadukan sehingga adonan yang lengket tersebut tetap stabil. Adonan tersebut kemudian ditambah tepung tapioka, sedikit demi sedikit. Penambahan tepung tapioka dalam pembuatan pempek selain sebagai bahan pengisi juga untuk memperbaiki tekstur dan menurunkan biaya produksi pempek, sehingga lebih ekonomis (Okada, 1985). Untuk memperoleh pempek dengan cita rasa yang enak dan tekstur yang baik, perbandingan antara ikan dan tepung tapioka yang ditambahkan adalah 1:1. Semakin banyak air dan tepung tapioka yang ditambahkan biaya produksi pempek semakin murah, namun mengurangi cita rasa produk pempek yang dihasilkan.

Dalam pengolahan pempek pencampuran antara ikan dan tepung tapioka tidak boleh dilakukan pengadukan yang terlalu kuat. Pengadukan yang terlalu kuat akan menyebabkan tekstur pempek yang dihasilkan keras, sehingga mengurangi penerimaan pempek. Hal ini disebabkan karena perlakuan fisik yang diberikan akan menyebabkan terjadinya reaksi intra dan intermolekul dari ikatan hidrogen molekul gula dari tapioka. Ikatan intramolekul tersebut akan menyebabkan rantai polisakarida yang satu berikatan dengan rantai polisakarida yang lainnya yang menyebabkan kekakuan sehingga tekstur menjadi keras (Greenwood \& Munro, 1979). Jenis dan mutu pati yang digunakan juga berpengaruh terhadap tekstur dan warna pempek yang dihasilkan. Pati yang bermutu baik akan menghasilkan pempek yang mempunyai elastisitas yang tinggi dan berwarna putih transparan. Untuk memperoleh pempek yang juicy dengan rasa yang lembut dan berair serta warna yang lebih transparan dapat digunakan pati yang telah dimodifikasi yang sekarang banyak beredar di pasaran. Pati yang telah dimodifikasi adalah pati yang mengalami perlakuan fisik atau kimia secara terkendali sehingga mengubah satu atau lebih sifat asalnya dan memperbaiki sifat-sifat pati (Redley, 1976). Sifat tapioka yang diinginkan antara lain stabilitas pada saat pembekuan, water holding capacity, tekstur, mouthfeel, dan daya awet produk hasil olahan pati. Perubahan dapat terjadi pada level molekuler tanpa mengubah penampakan dari granula patinya (Kusnandar, 2006). Untuk memperoleh tekstur yang lebih elastis maka pati tersebut harus mengandung banyak amilopektin dibandingkan dengan amilosenya. Amilose biasanya membentuk tekstur yang lemah dan amilopektin membentuk gel yang elastis. (Okada, 1985). Adonan ikan yang telah dicampur dengan tapioka kemudian dibentuk sesuai keinginan dan dipanaskan.

\section{c. Pemasakan}

Proses pemasakan dengan cara pemanasan bertujuan agar pati mengalami gelatinisasi, sehingga granula pati mengembang karena menyerap air dan proteinnya terdenaturasi. Kemampuan dari granula pati menyerap air disebabkan karena adanya gugus hidroksil pada rantai molekul pati (Barlina, 1985). Pemanasan dapat dilakukan dengan perebusan atau pengukusan. Perebusan dilakukan sampai proses gelatinisasi tapioka sempurna yang ditandai dengan mengapungnya pempek di permukaan air dan jika ditekan dengan tangan akan terasa lembut dan kenyal sampai ke bagian dalamnya. Lama perebusan dipengaruhi oleh bentuk dan ukuran pempek, namun biasanya membutuhkan waktu sekitar 10 - 30 menit. Oleh karena itu waktu pemasakan perlu diperhatikan, agar pempek dapat matang hingga ke bagian dalam saat digoreng untuk disajikan.

\section{Pengolahan Pempek Kering}

Pengeringan dimaksudkan untuk mengurangi kadar air produk melalui penguapan yang dapat dilakukan dengan cara penjemuran, pengeringan dengan alat pengering surya (solar dyer) atau alat pengering mekanik, dengan menggunakan energi listrik atau bahan bakar lainnya. Keuntungan dari pengeringan pempek adalah bahan menjadi lebih awet dengan volume bahan menjadi lebih kecil sehingga mempermudah distribusi dan memperluas pemasaran (Winarno et al., 1980). Pada pempek kering bentuk pempek yang sesuai untuk dikeringkan adalah pempek keriting. Bentuk keriting tersebut menyebabkan permukaan menjadi lebih luas sehingga proses pengeringan dapat dilakukan dengan lebih cepat. Untuk memperoleh pempek keriting digunakan alat tekan hidrolik. Adonan pempek dimasukkan ke dalam tabung yang terbuat dari stainless steel berbentuk silinder dan di bawahnya ditutup dengan plat besi yang berlubang-lubang. Mesin ini dioperasikan oleh dua orang, satu orang memutar ulir bagian atas, satu orang lagi menampung hasil uliran pempek. Pempek yang keluar berbentuk seperti mie besar, kemudian 
ditampung pada cup kecil sampai penuh sehingga membentuk bulatan-bulatan pempek keriting. Pempek keriting yang berbentuk bulat kemudian diatur di atas ancak bambu. Pempek kemudian dikukus di dalam panci pengukus yang berisi air mendidih selama 5 menit. Pengukusan yang terlalu lama atau lebih dari 5 menit menyebabkan adonan lembek, karena terjadi pengembangan granula pati yang disebabkan oleh penetrasi molekul-molekul air ke dalam granula pati dan air terperangkap dalam susunan molekul-molekul amilosa dan amilopektin (Birch, 1977). Keadaan ini menyebabkan bentuk pempek yang dihasilkan menjadi tidak bulat lagi, melainkan melebar dan lembek.

Pempek kemudian didinginkan dan disusun pada rak dalam alat pengering pempek. Pada tahap ini juga dilakukan sortasi terhadap pempek yang belum masak dan pempek yang mengalami gelatinisasi lebih lanjut (over cooking). Pempek yang belum masak ditandai dengan adanya warna putih dari pati yang belum membentuk gel pada proses pemanasan. Bila pempek yang dikeringkan belum masak, maka pempek kering yang dihasilkan, akan hancur bila direndam kembali ke dalam air (direhidrasi) sebelum diolah untuk disajikan. Demikian juga pempek yang terlalu masak, yang bentuknya tidak bulat lagi dipisahkan, karena proses pengeringannya memerlukan waktu yang lebih lama dibandingkan dengan yang lainnya. Rak yang sudah berisi pempek kemudian dimasukkan ke dalam oven pengering dan api di dalam oven dinyalakan. Suhu dalam oven secara perlahan akan naik dari suhu kamar menjadi suhu $60-70^{\circ} \mathrm{C}$ yang merupakan suhu maksimum di dalam ruang oven. Suhu maksimum tersebut akan tercapai dalam waktu 3-4 jam tergantung besar kecilnya api. Api yang terlalu besar akan menyebabkan warna pempek menjadi kekuningan. Hal ini disebabkan apabila pati dipanaskan pada suhu tinggi akan menghasilkan warna coklat yang disebabkan oleh pecahnya ikatan-ikatan karbon (Birch, 1977). Proses pengeringan pempek dilakukan selama 18 jam atau sampai gas dalam tabung gas ukuran kecil $(3 \mathrm{~kg})$ habis. Dengan cara pengeringan tersebut kadar air pempek yang dihasilkan kurang dari $10 \%$.

\section{Pengolahan Saus Pempek}

Saus atau cuko pempek dibuat dari gula aren dicampur dengan bumbu-bumbu seperti udang kering, bawang putih, cabe dan cuka. Pembuatan cuko atau saus dibuat dengan cara merebus 1 bagian gula aren dengan 1 bagian air, dan 1/10 bagian bumbu. Misalnya gula aren yang digunakan $1 \mathrm{~kg}$ maka air yang digunakan adalah 1 liter, sedangkan udang kering, cabe rawit dan bawang putih seberat $100 \mathrm{~g}$. Bumbubumbu tersebut dihaluskan kemudian baru dicampur dengan larutan gula. Adakalanya pengolah memfermentasikan terlebih dahulu bumbu yang digunakan selama semalam pada suhu kamar. Proses fermentasi tersebut bertujuan agar aroma bawang putih, cabe dan udang kering semakin tajam, sehingga saus yang dihasilkan terasa khas. Pada proses fermentasi tersebut akan terjadi pemecahan senyawa organik oleh bakteri anaerob menjadi senyawa senyawa yang sederhana, yang akan memberikan rasa dan bau yang khas (Winarno, 2007). Bumbu tersebut kemudian dicampurkan ke dalam air gula dan dimasak sampai mendidih. Setelah selesai, bumbu kemudian disaring sehingga ampas bumbubumbu yang digunakan dapat dihilangkan. Untuk bumbu pempek kering maka proses pemanasan bumbu dilakukan lebih lama sehingga membentuk adonan yang kental. Bumbu dikemas dalam kantong plastik dalam keadaan panas dan ditutup dengan menggunakan sealer. Bumbu tersebut dapat diencerkan kembali ketika mau disajikan.

\section{ALAT PENGERING PEMPEK}

Alat pengering pempek yang dirancang oleh Balai Besar Riset Pengolahan Produk dan Bioteknologi Kelautan dan Perikanan berupa ruang pengering yang berbentuk kabinet. Alat ini berukuran panjang 240 $\mathrm{cm}$, lebar $80 \mathrm{~cm}$ dan tinggi $120 \mathrm{~cm}$, dengan rangka terbuat dari besi siku, dinding terbuat dari triplek yang dilapisi dengan aluminium. Kabinet dibagi menjadi 3 ruang sehingga masing-masing berukuran $80 \mathrm{~cm} x$ $80 \mathrm{~cm} \times 120 \mathrm{~cm}$ dan masing-masing ruangan dilengkapi dengan pintu dan termometer untuk memonitor suhu seperti terlihat pada Gambar 1. Bagian atas alat pengering diberi dumper untuk mengatur aliran udara serta pembuangan uap air. Dalam proses pengeringan selain suhu pengeringan dan luas permukaan bahan maka salah satu faktor yang mempengaruhi proses pengeringan adalah aliran udara (Winarno, 2007).

Pada masing-masing ruang pengering dilengkapi dengan rak terbuat dari kawat ram dengan ukuran 74 $x 74 \mathrm{~cm}$ sebanyak 10 rak. Sumber panas dari gas elpiji yang dialirkan melalui pipa besi, ukuran $1 / 2$ inchi yang dilubangi dengan matabor ukuran paling kecil dan dialirkan ke ruang pengering. Untuk memperoleh penyebaran panas yang baik pipa gas diletakkan di atas rak no 3 dan no 6. Apabila kapasitas penuh (150 $\mathrm{kg}$ ), maka suhu ruangan pengering berkisar antara $45-55^{\circ} \mathrm{C}$ setelah api dinyalakan selama 2 jam, selanjutnya suhu tersebut akan stabil pada kisaran suhu $70-80^{\circ} \mathrm{C}$. Agar tingkat kekeringan pempek merata maka setiap 8 jam sekali dilakukan pemindahan rak, dengan cara menggeser rak yang tadinya dekat dengan sumber panas digeser dengan rak yang di bawahnya. Dengan cara ini pempek akan 


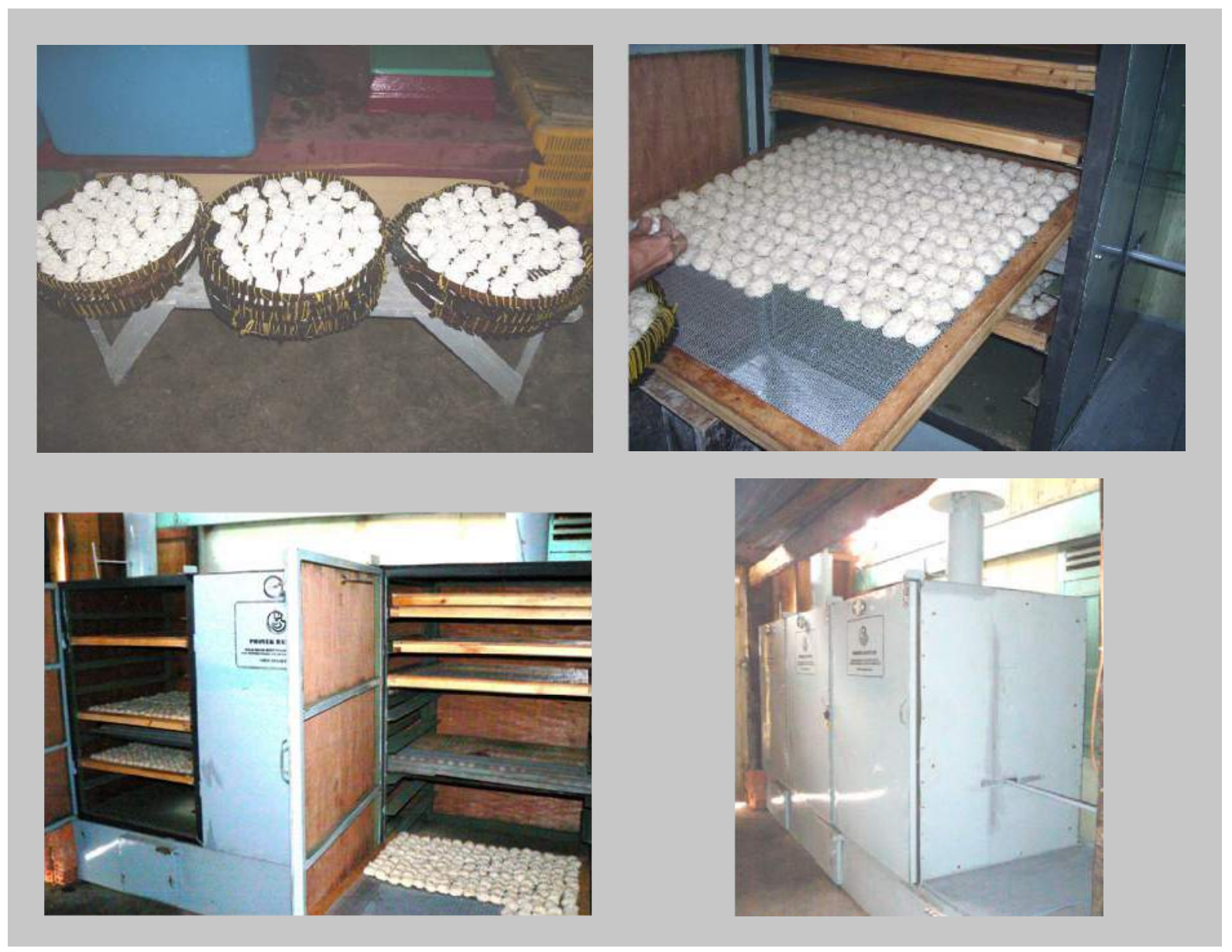

Gambar 1. Pempek keriting siap dikeringan dengan alat pengering mekanik.

kering dengan tingkat kekeringan yang cukup baik dan merata dengan kadar air berkisar antara 7,2$8,4 \%$.

Keunggulan menggunakan alat pengering ini adalah produksi pempek kering tidak lagi tergantung pada cuaca sehingga pengolah dapat memproduksi setiap hari. Pengeringan dapat dilakukan lebih cepat tanpa kontaminasi debu dan mikroorganisme lainnya, sehingga warna pempek lebih putih. Tingkat kekeringan pempek yang dihasilkan lebih tinggi, sehingga daya tahannya lebih lama. Biaya untuk pengeringan relatif murah yaitu Rp 500/kg, sehingga bila dibandingkan dengan pengeringan dengan menggunakan energi panas matahari, ongkos produksi yang dikeluarkan tidak jauh berbeda.

\section{USAHA DAN PEMASARAN PEMPEK}

Pempek sudah dikenal luas secara nasional sebagai makanan yang gurih dan lezat, sehingga penggemarnya ada di mana-mana di seluruh Indonesia bahkan juga di luar negeri. Di kota Palembang sendiri pempek merupakan hidangan yang biasa disantap setiap hari. Hasil penelitian menunjukkan bahwa sekitar $44,4-66,7 \%$ hotel dan restoran yang ada di Palembang menghidangkan pempek dalam menu makanannya kepada para tamu (Anon, 2008). Selain untuk memenuhi kebiasaan makan pempek penduduk setempat, pempek juga merupakan makanan khas oleh-oleh Palembang. Oleh karena itu industri rumah tangga dan toko yang menjual pempek tersebar dimana-mana dengan berbagai nama dagang. Demikian juga jumlah produk yang dihasilkan oleh para pengolah pempek relatif dapat terjual dengan baik. Di Palembang beberapa merk dagang pempek yang sudah terkenal membuka usahanya di beberapa tempat dan dikelola oleh keluarga. Tampaknya aspek modal belum menjadi masalah, selain dapat bantuan dari pemerintah, modal juga dapat diperoleh dari saudara-saudara mereka sendiri (family fund). Hal ini dilakukan karena relatif lebih mudah untuk mendapatkan modal, juga lebih efektif sehingga lebih cepat memutar roda usaha. Sedangkan industri pempek yang skalanya kecil, modal masih menjadi kendala usahanya. Hal ini disebabkan karena skala usaha yang dilakukan masih sangat tradisional dengan omset yang relatif kecil, 
sehingga menyebabkan mereka kesulitan memberikan jaminan untuk meminjam ke bank.

Bahan baku ikan yang digunakan dalam pengolahan pempek biasanya diperoleh dari para pemasok yang sudah menjadi langganan. Ikan yang dibeli dapat berupa daging ikan yang sudah dilumatkan, filet atau dalam bentuk gelondongan tergantung permintaan pengolah. Keuntungan pembelian daging lumat dan filet untuk bahan baku pempek adalah lebih praktis, para pengolah tidak melakukan preparasi lagi serta tidak menyisakan limbah yang dapat menjadi masalah lingkungan. Namun kerugiannya adalah tingkat kesegaran ikan tidak diketahui sehingga dapat berakibat buruk terhadap kualitas produk pempek yang dihasilkan. Harga ikan di pasaran bervariasi tergantung musim, apalagi bila bulan puasa menjelang lebaran harga ikan bisa dua kali lipat dari harga biasanya. Oleh karena itu pengolah yang mempunyai modal besar, biasanya mempunyai freezer untuk menyimpan bahan baku sebagai persediaan jika harga ikan melambung. Untuk tepung tapioka para pengolah lebih menyukai tepung tapioka dari Bogor dibandingkan dengan tepung tapioka dari Lampung. Tepung tapioka dari Bogor mempunyai warna yang lebih putih serta menghasilkan pempek yang lebih elastis dibandingkan dengan tepung tapioka dari Lampung. Diduga tepung tapioka dari Bogor mengandung lebih banyak amilopektin yang membentuk gel yang elastis (Okada, 1985).

Pempek yang sudah mempunyai nama dagang tidak sulit untuk dipasarkan. Promosi dilakukan oleh konsumen yang memberikan informasi kepada koleganya. Menurut keterangan pemilik toko sebagian besar pelanggan adalah wisatawan atau pendatang yang membeli oleh-oleh untuk kerabatnya. Pembelian pempek selain dapat dibawa langsung oleh pembeli dapat juga dikirim melalui jasa pengiriman luar kota seperti Jakarta, Bandung, Surabaya atau kota- kota besar lainnya. Beberapa toko juga sudah memanfaatkan internet untuk pemasarannya, sehingga pelanggan dapat membeli dengan cara online.

Dalam usahanya, para pedagang menengah ke atas sudah menggunakan alat-alat berupa mesin pengaduk adonan, freezer dan refrigerator. Pengaduk adonan digunakan untuk membantu mencampur ikan dengan garam, air es dan bumbu penyedap. Sedangkan freezer selain digunakan untuk menyimpan ikan juga digunakan untuk mengawetkan produk. Apabila produk tidak habis, pedagang menyimpannya di dalam refrigerator/kulkas dan dipanaskan kembali untuk dijual keesokan harinya. Kombinasi pengemasan vacuum dan penyimpanan beku dalam freezer, dapat mempertahankan daya simpan pempek hingga lebih dari 40 hari (Astawan, 2008). Untuk pempek kering pengolah menambah dua alat lagi berupa mesin hidrolik untuk membuat pempek keriting dan alat pengering pempek mekanik. Produk pempek kering karena kadar airnya rendah maka daya awetnya lebih lama sehingga jangkauan pemasarannya lebih luas. Kekurangan dari pempek kering tersebut adalah perlu direhidrasi (direndam dalam air) dan direbus kembali sebelum disajikan.

\section{ANALISIS USAHA PEMPEK}

Untuk mengevaluasi kelayakan usaha pengolahan pempek maka perlu dibuat analisis finansial secara sederhana. Tujuan dari analisis ini untuk mengetahui berapa tingkat keuntungan usaha yang berhasil diraih. Keuntungan yang diperoleh dapat digunakan untuk mengembangkan usaha dan menambah modal, peningkatan fasilitas dan teknologi serta pelayanan kepada konsumen. Perhitungan biaya yang sering dilakukan adalah 1) BEP (Break Event Point) yang merupakan suatu nilai di mana hasil penjualan produksi sama dengan biaya produksi sehingga pengeluaran sama dengan pendapatan, 2) ROI (Return of Invesment), merupakan nilai keuntungan yang diperoleh pengusaha dari setiap jumlah uang yang diinvestasikan dalam waktu periode tertentu serta 3) B/C (Benefit Cost Ratio) yang dihitung berdasarkan hasil penjualan dibagi dengan modal produksi. Dengan $B / C$ ini bisa dilihat kelayakan suatu usaha. Bila B/C nilainya 1 , berarti usaha tersebut belum mendapatkan keuntungan sehingga perlu pembenahan. Semakin kecil rasio, semakin besar kemungkinan perusahaan menderita kerugian.

\section{Analisis Usaha Pempek Basah}

Perhitungan analisis usaha pengolahan pempek basah ini dihitung berdasarkan produksi $100 \mathrm{~kg}$ pempek/hari. Peralatan yang diperlukan dalam pengolahan ini adalah alat bantu pengolahan seperti mincerlalat penggiling daging, mixerlalat pengaduk, freezer, dapat digunakan hingga 5 tahun, sedangkan alat perebus/pengukus, kompor, baskom, nampan, telenan dan pisau dapat digunakan selama 2 tahun. Dalam analisis usaha ini juga diperhitungkan pakaian kerja serta tunjangan lebaran karyawan. Perbandingan antara jumlah ikan : air es dan tapioka $=1: 1: 1$ dengan perhitungan hari kerja 25 hari per bulan dan bunga Bank $12 \%$ per tahun maka analisis usaha pengolahan pempek basah dapat dilihat pada Tabel 1 dan 2. Dari analisis usaha pempek basah apabila setiap hari bisa menjual pempek sebanyak $100 \mathrm{~kg}$ pempek basah maka keuntungan yang diperoleh kurang lebih $29,5 \%$ dari modal usaha dan biaya investasi dapat dikembalikan lagi kurang dari 4 putaran usaha atau setelah 4 bulan. 
Tabel 1. Biaya tidak tetap (variable cost) untuk produksi pempek basah selama 1 bulan

\begin{tabular}{llcrrr}
\hline No & \multicolumn{1}{c}{ Rincian } & Jumlah & $\begin{array}{c}\text { Harga satuan } \\
(\mathbf{R p})\end{array}$ & $\begin{array}{c}\text { Jumlah biaya } \\
(\mathbf{R p})\end{array}$ & Biaya 1 bulan \\
\hline 1 & Ikan filet tenggiri & $35 \mathrm{~kg}$ & 50,000 & $1,750,000$ & $43,750,000$ \\
2 & Garam & $2 \mathrm{~kg}$ & 2,000 & 4,000 & 100,000 \\
3 & Tepung tapioka & $35 \mathrm{~kg}$ & 8,000 & 280,000 & $7,000,000$ \\
4 & MSG & $2 \mathrm{~kg}$ & 12,000 & 24,000 & 600,000 \\
5 & Gas (tabung kecil) & $1 \mathrm{Tab}$ & 18,000 & 18,000 & 900,000 \\
6 & Listrik & & & 100,000 \\
7 & Tenaga kerja & 4 orang & 40,000 & 160,000 & $4,000,000$ \\
8 & Baju kerja & 2 stel x 4 orang & 50,000 & 400,000 & 66,670 \\
9 & Tunjangan lebaran & 4 Orang & 250,000 & $1,000,000$ & 9,090 \\
\hline \multicolumn{4}{c}{ JUMLAH } \\
\hline
\end{tabular}

Tabel 2. Biaya tetap (fixed cost) untuk produksi pempek basah selama 1 bulan

\begin{tabular}{llrrrr}
\hline No & Nama barang & Jumlah & $\begin{array}{r}\text { Harga satuan } \\
\text { (Rp) }\end{array}$ & $\begin{array}{r}\text { Jumlah biaya } \\
\text { (Rp) }\end{array}$ & $\begin{array}{r}\text { Penyusutan } \\
\text { (Rp) }\end{array}$ \\
\hline 1 & Pisau & 5 buah & 10,000 & 50,000 & 2,083 \\
2 & Meja kerja & 1 buah & $1,500,000$ & $1,500,000$ & 62,500 \\
3 & Baskom & 5 buah & 75,000 & 375,000 & 15,625 \\
4 & Panci perebus & 2 buah & $1,000,000$ & $2,000,000$ & 83,333 \\
5 & Kompor gas & 2 buah & 400,000 & 800,000 & 33,333 \\
6 & Tabung gas & 2 buah & 100,000 & 200,000 & 3,333 \\
7 & Mesin pengaduk & 1 buah & $10,000,000$ & $10,000,000$ & 166,667 \\
8 & Freezer & 1 Unit & $5,000,000$ & $5,000,000$ & 83,333 \\
9 & Mincer & 1 Unit & $3,000,000$ & $3,000,000$ & 50,000 \\
\hline & & JUMLAH & $\mathbf{2 2 , 9 2 5 , 0 0 0}$ & $\mathbf{5 0 0 , 2 0 7}$ \\
\hline
\end{tabular}

Modal usaha $=($ Jumlah biaya tidak tetap + Biaya tetap $)$

$$
=\text { Rp. 56.607.570,- + Rp. 22.925.000,- }
$$

$=$ Rp. $79.532 .570,-$

Bunga Bank $12 \%=12 \% \times$ Modal usaha

$=12 / 100 \times 1 / 12 \times \operatorname{Rp} .79 .532 .570,-$

$=$ Rp. 795.325,-

Kriteria produksi dan indikator kelayakan

1. Biaya tidak tetap

2. Penyusutan

3. Bunga Bank

Jumlah

Penjualan

Keuntungan/bulan

$\mathrm{B} / \mathrm{C}$

$\mathrm{ROI}$
Rp. 56.607.570,-

Rp. 500.207,-

Rp. 795.325,-

Rp. 57.903.102,-

100 kg x Rp. 30.000,- x 25 hr= Rp 75.000.000,-

Rp. $75.000 .000,--$ Rp. $57.903 .102,-=$ Rp. 17.096 .898

Rp. $75.000 .000,-/$ Rp. $57.903 .102,-=1.295$

Rp. 17.096.898,- / Rp. 57.903.102,- = 0.295 


\section{Analisis Usaha Pempek Kering}

Analisis usaha ini dihitung berdasarkan penggunaan satu unit alat pengolahan pempek kering kapasitas $150 \mathrm{~kg}$ dengan sekali proses. Peralatan yang diperlukan sama dengan pempek basah, yaitu mincer, alat pengaduk, freezer, serta 2 alat tambahan yaitu alat tekan hidrolik dan alat pengering pempek yang dapat digunakan hingga 5 tahun. Alat lainnya yaitu perebus/pengukus, kompor, baskom, nampan, telenan dan pisau dapat digunakan selama 2 tahun. Untuk pengolahan pempek kering $150 \mathrm{~kg}$ diperlukan tenaga laki dan perempuan sebanyak 6 orang dengan waktu kerja $8 \mathrm{jam}$. Perbandingan antara jumlah ikan : air es dan tapioka $=1: 1: 1$ dan rendemen yang diperoleh sebesar $60 \%$, maka dengan perhitungan hari kerja 25 hari per bulan dan bunga Bank $12 \%$ maka analisa usaha pengolahan pempek kering dapat dilihat pada Tabel 3 dan 4. Dibandingkan dengan usaha pempek basah, maka keuntungan yang diperoleh sedikit lebih tinggi yaitu sebesar $33,4 \%$ dari modal usaha dan investasi baru bisa dikembalikan kurang dari 3 putaran usaha atau 3 bulan.

Tabel 3. Biaya tidak tetap (variable cost) untuk produksi pempek kering selama 1 bulan

\begin{tabular}{llcrrr}
\hline No & Rincian & Jumlah & $\begin{array}{c}\text { Harga satuan } \\
(\mathbf{R p})\end{array}$ & $\begin{array}{c}\text { Jumlah biaya } \\
(\mathbf{R p})\end{array}$ & Biaya 1 bulan \\
\hline 1 & Ikan filet tenggiri & $70 \mathrm{~kg}$ & 50,000 & $3,500,000$ & $87,500,000$ \\
2 & Garam & $4 \mathrm{~kg}$ & 2,000 & 8,000 & 200,000 \\
3 & Tepung tapioka & $70 \mathrm{~kg}$ & 8,000 & 560,000 & $14,000,000$ \\
4 & MSG & $4 \mathrm{~kg}$ & 12,000 & 48,000 & $1,200,000$ \\
5 & Gas (tabung kecil) & $2 \mathrm{Tab}$ & 18,000 & 36,000 & 900,000 \\
6 & Listrik & 6 orang & 40,000 & & 100,000 \\
7 & Tenaga kerja & 2 stel x 6 Org & 50,000 & 240,000 & $6,000,000$ \\
8 & Baju kerja & 6 orang & 250,000 & $1,500,000$ & 50,000 \\
9 & Tunjangan lebaran & & JUMLAH & $\mathbf{6 , 4 9 2 , 0 0 0}$ & $\mathbf{1 1 0 , 0 8 6 , 3 7 0}$ \\
\hline
\end{tabular}

Tabel 4. Biaya tetap (fixed cost) untuk produksi pempek kering selama 1 bulan

\begin{tabular}{llrrrr}
\hline No & Nama barang & Jumlah & $\begin{array}{r}\text { Harga satuan } \\
(\mathbf{R p})\end{array}$ & $\begin{array}{c}\text { Jumlah } \\
(\mathbf{R p})\end{array}$ & $\begin{array}{c}\text { Penyusutan } \\
(\mathbf{R p})\end{array}$ \\
\hline 1 & Pisau & 5 buah & 10,000 & 50,000 & 2,083 \\
2 & Meja kerja & 1 buah & $1,500,000$ & $1,500,000$ & 62,500 \\
3 & Baskom & 5 buah & 75,000 & 375,000 & 15,625 \\
4 & Panci perebus & 2 buah & $1,000,000$ & $2,000,000$ & 83,333 \\
5 & Kompos gas & 2 buah & 400,000 & 800,000 & 33,333 \\
6 & Tabung gas kecil & 2 buah & 100,000 & 200,000 & 13,333 \\
7 & Mesin pengaduk & 1 buah & $10,000,000$ & $10,000,000$ & 166,670 \\
8 & Freezer & 1 Unit & $5,000,000$ & $5,000,000$ & 83,340 \\
9 & Mincer & 1 Unit & $3,000,000$ & $3,000,000$ & 50,000 \\
10 & Alat pengepres hidrolik & 1 Unit & $6,000,000$ & $6,000,000$ & 100,000 \\
11 & Alat pengering pempek & 1 Unit & $15,000,000$ & $15,000,000$ & 250,000 \\
\hline & & JUMLAH & & $\mathbf{4 3 , 9 2 5 , 0 0 0}$ & $\mathbf{8 6 0 , 2 1 3}$ \\
\hline
\end{tabular}




$$
\begin{aligned}
& \text { Modal usaha }=\text { (Jumlah biaya tidak tetap + Biaya tetap }) \\
& =\text { Rp. } 110.086 .370,-+ \text { Rp. } 43.925 .000,- \\
& =\text { Rp. } 154.011 .370,- \\
& \begin{aligned}
\text { Bunga Bank } 12 \% & =12 \% \times \text { Modal usaha } \\
& =12 / 100 \times 1 / 12 \times \text { Rp. } 154.011 .370,- \\
& =\text { Rp. } 1.540 .113,-
\end{aligned}
\end{aligned}
$$

Kriteria produksi dan indikator kelayakan
1. Biaya tidak tetap
Rp. 24.088.370,-
2. Penyusutan
Rp. 860.213,-
3. Bunga Bank
Rp. 1.540.113,-
Jumlah
Rp. 126.488.696,-
Penjualan
$150 \mathrm{~kg} \times$ Rp. 45.000,- $\times 25$ hr = Rp. 168.750.000,-
Keuntungan/bulan
Rp. 168.750.000,- - Rp. 126.488.696,- = Rp. 42.261.304,-
$\mathrm{B} / \mathrm{C}$
Rp. $168.750 .000,-/$ Rp. 126.488.696,- = 1.334
$\mathrm{ROI}$
Rp. 42.261.304,- / Rp. 126.488.696,- = 0.334

\section{PENUTUP}

Pempek merupakan salah satu usaha diversifikasi pengolahan hasil perikanan yang potensial untuk dikembangkan. Berdasarkan analisa usaha yang cukup menguntungkan, pengolahannya yang sederhana, bahan baku yang mudah diperoleh, serta pangsa pasarnya yang cukup luas karena digemari oleh sebagian besar masyarakat, maka usaha pengolahan pempek sangat prospektif untuk dikembangkan. Usaha ini dapat menjadi sumber pendapatan bagi masyarakat dan menambah kesejahteraan keluarga. Dalam usaha pengolahan makanan maka yang perlu diperhatikan adalah masalah keamanan pangan. Untuk itu selain bahan baku, sanitasi dan higiene harus diperhatikan terutama kebersihan tempat pengolahan, peralatan yang digunakan dan kesehatan pekerja. Untuk mengembangkan usaha ini, dukungan dari Pemerintah terutama Dinas Perikanan sangat diperlukan terutama untuk kaderisasi dan pembinaan, serta membantu usaha pencarian modal usaha.

\section{DAFTAR PUSTAKA}

Anonim. 2006. Pempek Palembang. Http/www/Pempek Palembang. Diakses pada tanggal 23 Februari 2007. 3 pp.

Anonim. 2008. Pempek. Http/www/ip.wikipedia.org/wiki/ pempem/26 k. Diakses pada tanggal 23 Februari 2009. 7 pp
Astawan, M. 2008. Makanan Tradisional Kerajaan Sriwijaya. Sriwijaya Post, 8 Agustus 2008.

Birch, G.G. 1977. Chemical, physical and biological changes in carbohydrates induced by thermal processing. In Hoyem, T. and Kvalo, O. (eds.). Physical, Chemical and Biological in Food Caused By Thermal Processing. Applied Science Publishers Limited London.

Barlina, R. 1985. Perubahan Sifat Fisik, Kimia dan Biologi Karbohidrat Akibat Proses Thermal. Fakultas Pascasarjana IPB, Bogor. $21 \mathrm{pp}$.

Gopakumar, K. 1997. Tropical Fishery Products. Science Publishers, Inc. New Humpshire.USA. p. 69-99.

Greenwood. C.T. and Munro, D.N. 1979. Carbohydrate. In Priestley, R.J. (ed.). Effects of Heating on Foodstuffs. Apllied Science Publishers Ltd. London.

Kusnandar, F. 2006. Modifikasi Pati dan Aplikasinya pada Industri Pangan. FOODREVIEW Indonesia April 2006. p. 26-31.

Lee, C.M. 1997. Functional additives: proteins and gums. In Park, J.W. (ed.). Surimi and Surimi Seafood. Oregon State University, Astoria, OR. p. 138-162

Niwa, E. 1985. Functional aspect of surimi. Proceedings of the International Symposium on Engineered Seafood Including Surimi. Seattle, Washington. p.141-167.

Okada, M. 1985. Ingredients on gel texture. Proceedings of the International Symposium on Engineered Seafood Including Surimi. Seattle, Washington. p. 515-530.

Tanaka, M. 2008. Teknik pasca panen produk perikanan. Panduan Bantuan Teknis untuk Industri Ikan dan 
Th. D. Suryaningrum dan I. Muljanah

Udang Skala Kecil dan Menengah di Indonesia. Kerjasama DKP- JICA. 77 pp.

Redley, J.A. 1976. Industrial Uses of Strach and Its Derivatives. Applied Science Publishers LTD, London. $259 \mathrm{pp}$.

Suzuki, T. 1981. Characteristics of fish meat and fish protein. Ch. 1 in Fish and Krill Protein: Processing
Technology. Applied Science Publishers Ltd., Essex, England. p. 1-55.

Winarno, F.G. 2007. Teknobiologi Pangan. M Brio Press. Bogor. 308 pp.

Winarno, F.G., Fardiaz, S., dan Fardiaz, D. 1980. Pengantar Teknologi Pangan. PT Gramedia, Jakarta. $92 \mathrm{pp}$. 